\title{
Acceleration in linear growth after splenectomy for hypersplenism in homozygous sickle cell disease
}

\author{
Atul Singhal, Peter Thomas, Tara Kearney, Sivarajan Venugopal, Graham Serjeant
}

\begin{abstract}
Chronic hypersplenism in homozygous sickle cell (SS) disease markedly increases haemolysis and the resulting erythropoietic expansion is likely to have a high metabolic cost. Splenectomy for hypersplenism in SS disease is followed by highly significant changes in haematological indices and an increase in height, but not weight, velocity. This pattern is similar to that observed in the trichuris dysentery syndrome after treatment, and differs from the increases in both height and weight velocity that follow nutritional supplementation of severely malnourished children. It is postulated that accelerated linear growth after the reduction in erythropoietic stress may implicate a specific nutrient deficiency in hypersplenic children with SS.

(Arch Dis Child 1995; 72: 227-229)
\end{abstract}

Keywords: sickle cell disease, hypersplenism, growth.

The spleen is central to much of the early pathology in homozygous sickle cell (SS) disease. Typically splenic enlargement occurs in the first year of life and is followed by progressive fibrosis generally attributed to the development of intravascular sickling. This natural history may be punctuated, in some patients, by episodes of acute splenic enlargement with life threatening falls in haemoglobin (acute splenic sequestration) or by sustained enlargement with chronic sequestration (chronic hypersplenism). Chronic hypersplenism in SS disease markedly increases haemolysis and the resulting erythropoietic expansion is likely to have a high metabolic cost. Relief of hypersplenism by splenectomy results in lowered protein turnover ${ }^{1}$ and an increase in height velocity. ${ }^{2}$ Hypersplenism in SS disease appears to impose a high metabolic load which competes with the requirements for normal growth. This hypothesis has been tested in a group of SS children by observations before and after splenectomy.

Patients and methods

The patients attended the Sickle Cell Clinic at the University Hospital of the West Indies, Kingston, Jamaica. Review of patient records identified 32 children (13 boys) with SS disease aged 1-11 years who had splenectomy for hypersplenism in the period 1 January 1973 to 31 December 1991. Children below 1 year were excluded because of difficulty in obtaining reliable growth data and those over 11 years were excluded to avoid the possible confounding effects of the pubertal growth spurt. Median age at splenectomy (range) was $4 \cdot 7$ years $(1 \cdot 4-9 \cdot 3)$.

The diagnosis of SS disease was based on standard criteria ${ }^{3}$ and haematological indices were measured in an electronic counter (Coulter S plus 4, Coulter Electronics). Fetal haemoglobin was measured by the alkali denaturation method of Betke et al. ${ }^{4}$ Haematological indices including haemoglobin concentration, mean cell volume (MCV), mean cell haemoglobin $(\mathrm{MCH})$, and mean cell haemoglobin concentration (MCHC) were measured in children three months before splenectomy (while untransfused) and three months after splenectomy (when transfused blood had disappeared). Patients were not given regular transfusion treatment for hypersplenism and were transfused only if deemed necessary at the time of operation. Chronic hypersplenism was arbitrarily defined as a spleen of $4 \mathrm{~cm}$ or more below the left costal margin, haemoglobin concentration $<60 \mathrm{~g} / \mathrm{l}$, reticulocyte counts $>15 \%$, and platelet counts $<200 \times 10^{9} / 1$, all recorded on at least two occasions three months or more apart.

Height was measured with a wall mounted stadiometer (Holtain Ltd) accurate to $1 \mathrm{~mm}$, and weight in light clothing but without shoes on a beam balance (Detecto Ltd) accurate to $0.1 \mathrm{~kg}$. The equipment was regularly calibrated and measurements made by nursing or medical staff trained in the procedures. Height and weight was measured every three months and the nearest available data used for computing velocities over three six month periods: six months before splenectomy and the first and second six months after splenectomy. As velocities are expressed over one year intervals, the six month height or weight increment was doubled and increments, where actual measurements were available over shorter or longer intervals, multiplied by an appropriate factor. Height and weight at the time of splenectomy were available before operation in 22 patients and immediately after operation in 10. Weight velocities, before and after splenectomy, were also calculated taking account of spleen size (median spleen weight $0.32 \mathrm{~kg}$, range $0 \cdot 07-0 \cdot 78)$. Standardised scores ( scores) for height, weight, weight/height, height velocity, and weight velocity in hypersplenic patients were calculated using age and sex specific standards derived from a cohort of 200 SS subjects. 

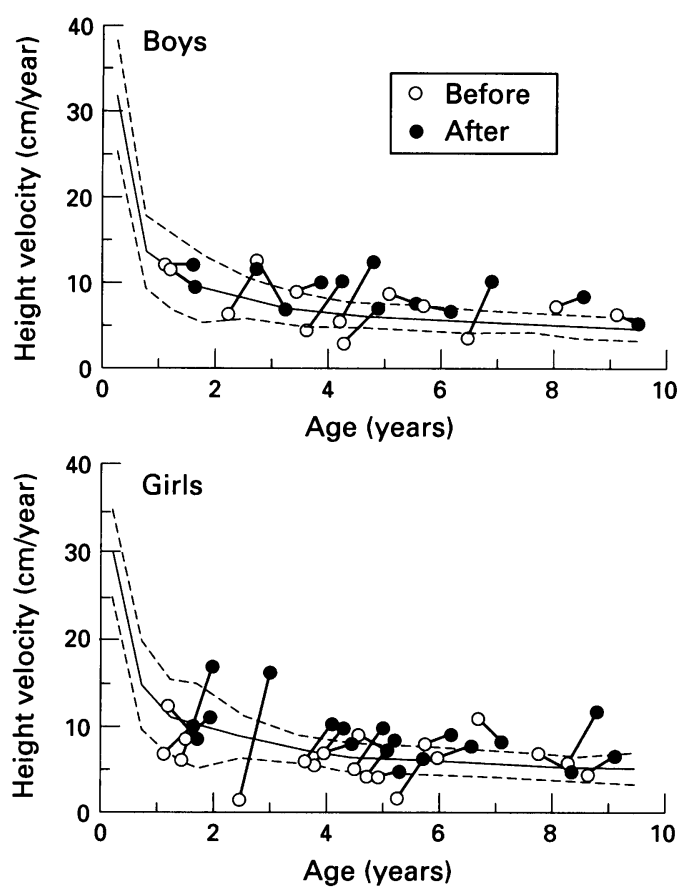

Height velocity calculated over six month intervals before and after splenectomy for hypersplenism connected by a straight line in individual boys and girls. Height velocities (10th, 50th, and 90th centiles) for a cohort of 200 famaican SS children, calculated over 12 month intervals, are given for comparison.

The statistical significance of changes in height and weight velocity, height, weight, and weight/height (expressed in original units or as $\mathrm{z}$ scores) and haematology before and after splenectomy were assessed using the paired $t$ test (which excludes subjects without data both before and after splenectomy). The one sample $t$ test was used to assess whether standardised scores for growth indices were from a population with a mean of zero.

\section{Results}

The mean (SD) height velocity in the six months before splenectomy was $7 \cdot 0(3 \cdot 1)$ $\mathrm{cm} /$ year $(95 \%$ confidence interval (CI) 6.0 to $8 \cdot 1$ ) and $9 \cdot 2(2 \cdot 8) \mathrm{cm} /$ year $(95 \% \mathrm{CI} 8 \cdot 2$ to $10 \cdot 2$ ) in the six months after operation, representing a mean increase of $2 \cdot 2 \mathrm{~cm} /$ year $(95 \%$ CI 0.7 to $3 \cdot 7$ ). In the second six months postoperatively, the mean (SD) height velocity was $6.6(3 \cdot 1) \mathrm{cm} /$ year $(95 \%$ CI $5 \cdot 5$ to $7 \cdot 8)$. The changes in height velocity associated with splenectomy, relative to values observed in control SS children, are shown in the figure and as standardised scores in table 1.
The mean (SD) weight velocity in the six months before operation was $1.5(2 \cdot 0) \mathrm{kg}$ /year (95\% CI 0.8 to $2 \cdot 2)$ and in the six months after operation was $2 \cdot 0(2 \cdot 0) \mathrm{kg} /$ year $(95 \% \mathrm{CI}$ 1.2 to $2 \cdot 7)$, a mean increase of $0.5 \mathrm{~kg} /$ year $(95 \%$ CI -0.7 to $1 \cdot 6)(p=0 \cdot 4)$. Comparing weight velocities that had been adjusted for spleen weight showed a mean increase of 0.6 $\mathrm{kg} /$ year $(95 \%$ CI -0.6 to 1.8$) \quad(\mathrm{p}=0.3)$. Weight velocities expressed as $\mathrm{z}$ scores (table 1) also failed to show significant increases after splenectomy.

The increase in postoperative height velocity occurred despite normal $\mathrm{z}$ scores for height and weight, six months before and at splenectomy and normal $\mathrm{z}$ scores for height and weight velocity in the six months before operation (table 1).

Body mass index (BMI, calculated as weight/height ${ }^{2}$ ) of hypersplenic patients at splenectomy (mean (SD) $15 \cdot 2(1 \cdot 2) \mathrm{kg} / \mathrm{m}^{2}$, range $13 \cdot 3-18 \cdot 0)$ was similar to that six months before operation $(15 \cdot 4(1 \cdot 5)$, range $13 \cdot 0-19 \cdot 4)$ $(p=0 \cdot 2)$ and the range did not differ from the BMI of the cohort of 200 SS children aged 1-10 years (range $11 \cdot 1-19 \cdot 9)$. Six months postoperatively, the BMI had fallen (mean (SD) $14 \cdot 7(1 \cdot 2)$, range $12 \cdot 9-17 \cdot 2)$ significantly $(\mathrm{p}=0.004)$ and remained low 12 months postoperatively $(14 \cdot 8(1 \cdot 3)$, range $13 \cdot 1-17 \cdot 2)$.

After splenectomy, there were significant increases in haemoglobin concentration, packed cell volume, MCHC, red cell count, and platelet count and a fall in reticulocytes (table 2). As both height velocity and many haematological indices change after splenectomy, the relationship of change in height velocity to presplenectomy haematological indices and to degree of change in these indices was examined to search for possible correlates. Of the presplenectomy indices, only MCHC was significantly related and haemoglobin, red cell count, and MCV were of borderline significance (table 3). Multiple regression confirmed $\mathrm{MCHC}$ as the only independent correlate of the presplenectomy haematology with change in height velocity. Change in height velocity was not related to the serum iron concentration $(r=-0.09$, $\mathrm{p}=0.63)$, iron binding capacity $(r=0.32$, $\mathrm{p}=0.09)$, transferrin saturation $(r=-0.14$, $\mathrm{p}=0.46)$, or serum folate $(r=0.12, \mathrm{p}=0.58)$ before splenectomy. Examining the change in haematological values, only $\mathrm{MCHC}$ was significantly related to change in height velocity and this was confirmed on multiple regression.

Table 1 Standardised scores ( $z$ scores) for growth indices before and after splenectomy

\begin{tabular}{|c|c|c|c|c|c|c|c|c|c|c|c|c|c|c|}
\hline & \multicolumn{2}{|c|}{ Before operation } & \multicolumn{2}{|c|}{ At operation } & \multicolumn{2}{|c|}{ Postoperative (1) } & \multicolumn{2}{|c|}{ Postoperative (2) } & \multicolumn{6}{|c|}{ Comparison of columns 1-4 } \\
\hline & No & Mean $(S D)$ & No & Mean (SD) & No & Mean (SD) & No & Mean (SD) & $1 \mathrm{v} 2$ & $1 \times 3$ & $1 \mathrm{v} 4$ & $2 \times 3$ & $2 \times 4$ & $3 v 4$ \\
\hline $\begin{array}{l}\text { Height velocity } \\
\text { Height } \\
\text { Weight velocity } \\
\text { Weight } \\
\text { Weight/height }\end{array}$ & $\begin{array}{l}32 \\
32 \\
31 \\
32 \\
31\end{array}$ & $\begin{array}{r}-0.01(1.83) \\
-0.07(1.03) \\
-0.32(2.46) \\
0.30(1.18) \\
0.43(1.20)\end{array}$ & $\begin{array}{l}3 \overline{2} \\
\overline{31} \\
31\end{array}$ & $\begin{array}{c}-0.13(0.94) \\
0.24(0.98) \\
0.41(0.92) \dagger\end{array}$ & $\begin{array}{l}32 \\
32 \\
31 \\
32 \\
32\end{array}$ & $\begin{array}{l}1.82(1.75) \mathrm{ttt} \\
0.16(1.01) \\
0.12(2.47) \\
0.33(1.16) \\
0.30(1.12)\end{array}$ & $\begin{array}{l}29 \\
29 \\
28 \\
29 \\
28\end{array}$ & $\begin{array}{l}0.10(2.46) \\
0.27(1.01) \\
0.51(2.33) \\
0.39(1.14) \\
0.49(1.18) \dagger\end{array}$ & $\begin{array}{l}\overline{\text { NS }} \\
\overline{\mathrm{NS}} \\
\mathrm{NS}\end{array}$ & $\begin{array}{l}\star \star \star \\
\star \star \star \\
\text { NS } \\
\text { NS } \\
\text { NS }\end{array}$ & $\begin{array}{l}\text { NS } \\
\star \star \\
\text { NS } \\
\text { NS } \\
\text { NS }\end{array}$ & $\begin{array}{l}\bar{\star} \\
\bar{N} \\
\text { NS }\end{array}$ & $\begin{array}{l}\overline{-} \\
\star \star \star \\
\bar{N} \\
\text { NS }\end{array}$ & $\begin{array}{l}\star \star \\
\text { NS } \\
\text { NS } \\
\text { NS } \\
\text { NS }\end{array}$ \\
\hline
\end{tabular}

Comparison using paired $t$ test; ${ }^{\star \star \star} \mathrm{p}<0.001,{ }^{\star \star} \mathrm{p}<0 \cdot 01,{ }^{\star} \mathrm{p}<0.05$; one sample $t$ test; $\mathrm{t}+\mathrm{p}<0 \cdot 001, \mathrm{tp}<0.05$.

Height and weight velocities were measured over $0-6$ months before splenectomy, $0-6$ months postoperatively (1), and $6-12$ months postoperatively (2)

Weight velocities calculated without consideration of splenic weight.

WS=not significant. 
Table 2 Changes in haematology after splenectomy for hypersplenism

\begin{tabular}{|c|c|c|c|}
\hline & $\begin{array}{l}\text { Mean (SD) before } \\
\text { splenectomy }(n=29)\end{array}$ & $\begin{array}{l}\text { Mean change }(95 \% C I) \\
\text { after splenectomy }(n=27)\end{array}$ & $\begin{array}{l}\text { p Value } \\
\text { (paired } \mathrm{t} \text { test) }\end{array}$ \\
\hline Haemoglobin $(\mathrm{g} / \mathrm{l})$ & $51(12)$ & 32 (26 to 37$)$ & $<0.001$ \\
\hline Packed cell volume & $0.17(0.04)$ & $0.08(0.07$ to 0.10$)$ & $<0.001$ \\
\hline $\operatorname{MCHC}(\mathrm{g} / \mathrm{l})$ & $309(32)$ & $23(7$ to 39$)$ & 0.007 \\
\hline Red cell count $\left(\times 10^{12} / 1\right)$ & $2.0(0.5)$ & $1.1(0.9$ to 1.3$)$ & $<0.001$ \\
\hline $\mathrm{MCV}(\mathrm{f})$ & & $-3 \cdot 0(-6 \cdot 1$ to $0 \cdot 1)$ & 0.06 \\
\hline $\mathrm{MCH}(\mathrm{pg})$ & $26 \cdot 3(4 \cdot 1)$ & $0.7(-0.9$ to 2.3$)$ & 0.4 \\
\hline Recticulocyte count (\%) & $20 \cdot 0(8 \cdot 3)$ & $-11.3(-14.7$ to -8.0$)$ & $<0.001$ \\
\hline Platelet count $\left(\times 10^{9} / 1\right)$ & $231(109)$ & $336(252$ to 420$) t$ & $<0.001$ \\
\hline
\end{tabular}

*Variable not normally distributed: median (range) of MCV is 85 (69-117); $\mathfrak{n}=21$.

\section{Discussion}

Hypersplenism is associated with excessive red cell destruction in SS disease with mean red cell life spans as short as two days. ${ }^{5}$ In the face of this haemolysis, haemoglobin concentrations of $30-60 \mathrm{~g} / \mathrm{l}$ can only be maintained by marked erythropoietic expansion and consequently increased demands of amino acids and calories that may compete with demands for growth. The normal mean standardised scores for height (compared with a cohort of SS children) suggest that SS patients with hypersplenism as a group adapt to the increased erythropoietic demands and maintain normal growth.

Splenectomy for hypersplenism reduces haemolytic rate and was associated with an increase in height velocity. The need to document height velocity over periods as short as six months inevitably leads to greater variability as evidenced by the greater than expected spread in presplenectomy values apparent in the figure. Despite this source of inaccuracy, there was a significant increase in height velocity after splenectomy suggesting that processes compensating for hypersplenism before splenectomy produce a temporary growth spurt once the excessive erythropoietic stress is removed. Similar observations of accelerated height velocity have also been made in Crohn's disease $^{6}$ and trichuris infection ${ }^{7}$ after treatment.

The increase in weight velocity after splenectomy for hypersplenism was not significant. Adjusting for splenic weight had little effect on the change in weight velocity after surgery,

Table 3 Correlation between change in height velocity and haematological indices in SS patients with hypersplenism

\begin{tabular}{|c|c|c|c|c|}
\hline & \multicolumn{2}{|c|}{$\begin{array}{l}\text { Haematology before splenectomy } \\
(n=29)\end{array}$} & \multicolumn{2}{|c|}{$\begin{array}{l}\text { Change in haematology } \\
(n=27)\end{array}$} \\
\hline & $\begin{array}{l}\text { Correlation } \\
\text { coefficient }\end{array}$ & p Value & $\begin{array}{l}\text { Correlation } \\
\text { coefficient }\end{array}$ & p Value \\
\hline Haemoglobin & 0.35 & 0.06 & -0.22 & $0 \cdot 28$ \\
\hline Packed cell volume & $0 \cdot 21$ & $0 \cdot 28$ & 0.00 & 0.99 \\
\hline $\mathrm{MCHC}$ & $0 \cdot 38$ & 0.04 & -0.47 & 0.01 \\
\hline Red cell count & 0.35 & 0.06 & 0.08 & 0.68 \\
\hline MCV & $-0.35^{\star}$ & 0.06 & 0.02 & 0.93 \\
\hline MCH & $-0 \cdot 10$ & 0.62 & -0.32 & $0 \cdot 10$ \\
\hline Reticulocyte count & 0.00 & 0.99 & -0.05 & 0.81 \\
\hline Platelet count & -0.07 & 0.72 & $0.31 \dagger$ & $0 \cdot 18$ \\
\hline Haemoglobin $\mathrm{A}_{2}$ & $0 \cdot 17$ & 0.37 & - & - \\
\hline Fetal haemoglobin $\neq$ & $0 \cdot 04^{\star}$ & 0.85 & - & - \\
\hline
\end{tabular}

`In transformation used; $\nmid \mathrm{n}=21$. $¥$ Not routinely measured after splenectomy. although such adjustment must be very inaccurate, splenic weight being influenced by random factors such as the degree of sequestration at the time of operation and the interval between clamping the splenic artery and vein. The increase in height velocity after splenectomy clearly exceeded any increase in weight velocity, contrasting with the effect of nutritional supplementation of severely malnourished children in whom an increase in weight velocity precedes an increase in height velocity. ${ }^{8}$ This suggests that the accelerated linear growth is not simply consequent on a general improvement in nutrition but that hypersplenism produces specific nutritional demands. The fall in $\mathrm{BMI}$ in the six months postoperatively is consistent with this observation and argues against a general energy deficiency ${ }^{9}$ but in favour of a specific defect such as the marginal availability of glycine in this condition. ${ }^{10}$

The failure of the increase of height velocity after splenectomy to correlate with an improvement in haematological indices was surprising and suggests that the acceleration in growth was not related to any of these factors. Changes in height velocity after splenectomy correlated positively with preoperative $\mathrm{MCHC}$ values and negatively with changes in $\mathrm{MCHC}$ levels. These observations, and the borderline significant correlations with preoperative haemoglobin concentrations and red cell counts, suggest that children able to maintain higher haemoglobin production in the face of increased erythropoietic stress are better equipped for a growth spurt postoperatively.

The acceleration in linear growth, consequent on removal of an excessive erythropoietic stress in hypersplenism in SS disease, may also have implications for the widely recognised growth abnormalities in other patients with SS disease.

1 Badaloo A, Emond A, Venugopal S, Serjeant G, Jackson AA. The effect of splenectomy on whole body protein turnover in homozygous sickle cell disease. Acta Paediatr Scand 1991; 80: 103-5.

2 Emond AM. The spleen in sickle cell disease in childhood. Cambridge: University of Cambridge, 1987. (MD thesis.) Serjeant GR. Sickle cell disease. 2nd Ed. Oxford: Oxford University Press, 1992.

4 Betke M, Marti HR, Schlicht I. Estimation of small percentages of foetal haemoglobin. Nature 1959; 184: 1877-8.

5 Rossi EC, Westring DW, Santos AS, Gutierrez J. Hypersplenism in sickle cell anemia. Arch Intern Med 1964; 114: 408-12.

6 Lipson AB, Savage MO, Davies PSW, Bassett K, Shand WS, Walker-Smith JA. Acceleration of linear growth following intestinal resection for Crohn's disease. Eur $\mathfrak{f}$ Pediatr 1990; 149: 687-90.

7 Cooper ES, Bundy DAP, MacDonald TT, Golden MHN. Growth suppression in the trichuris dysentery syndrome. Eur $\mathcal{f}$ Clin Nutr 1990; 44: 285-91.

8 Walker SP, Golden MHN. Growth in length of children recovering from severe malnutrition. Eur $f$ Clin Nutr 1988; 42: 395-404.

9 Heyman MB, Vichinsky E, Katz R, et al. Growth retardation in sickle cell disease treated by nutritional support. Lancet 1985; i: 903-6.

10 Jackson AA. The use of stable isotopes to study nitrogen metabolism in sickle cell disease. In: Velazques A, Bourges H, eds. Genetic factors in nutrition. New York: Academic Press, 1984: 297-315. 